\title{
The interaction of history and STEM learning goals in teacher-developed curriculum materials: opportunities and challenges for STEAM education
}

\author{
Wonyong Park ${ }^{1} \cdot$ Hohee $\mathrm{Cho}^{2}$
}

Received: 8 August 2021 / Revised: 28 December 2021 / Accepted: 10 January 2022 / Published online: 29 January 2022

(c) The Author(s) 2022

\begin{abstract}
Although the integration of subjects in the curriculum has been advocated in recent years, there exist limited opportunities for teachers of different subjects to implement integrated curricula in schools collaboratively. In this paper, we consider history as a humanities subject that could be integrated with STEM and explore the diverse history-related learning goals found in teacher-developed STEAM curriculum materials. Using integrated STEAM curricula developed by 13 cross-subject teacher teams in Korea, we analyze the presentation of history-related learning goals in the curricula and report several patterns identified across the curricula. First, the majority of the curricula aimed for the learners to identify themselves in their regional and national histories, but other levels of identification were also aimed for. Second, all the curricula included goals related to historical analysis skills, which were sometimes integrated with scientific inquiry skills. Third, we found several goals related to eliciting students' moral response to history, particularly when the curriculum topic concerned issues at the national level. Fourth, the integration of subjects allowed for exhibiting learners' historical understanding through various activities and in explanatory, persuasive, and imaginative manners. Overall, the analysis pointed to several ways in which the goals of history learning can interact with those of STEM learning, which can be useful for future research and practice in integrated curriculum. We discuss some potential challenges of integrating history with STEM, such as issues that can arise from the use of the "nation" as a context for STEAM learning.
\end{abstract}

Keywords STEAM $\cdot$ History education $\cdot$ Integrated curriculum $\cdot$ Science education $\cdot$ Teacher collaboration

\section{Introduction}

As highlighted by recent educational reform and vision documents (NGSS Lead States, 2013; OECD, 2020), the need for interdisciplinary approaches in STEM education is increasingly recognized among educational researchers. Broggy et al. (2017) suggested that interdisciplinary teaching is inherently student centered and can positively influence students' achievement and interest in STEM subjects by highlighting the relevance of STEM to students' lives. Such

Hohee Cho

hohee.cho@history.ox.ac.uk

Wonyong Park

w.park@soton.ac.uk

1 Southampton Education School, University of Southampton, Southampton, UK

2 Faculty of History, University of Oxford, Oxford, UK attention to integrated curriculum has been in part motivated by the complex socioscientific issues that humanity has been faced with in recent decades, such as climate change, infectious diseases, and environmental disasters, which necessitates a holistic consideration from not only STEM but also political, ethical, and social perspectives. Having balanced views and making informed decisions about such issues are core capabilities that students need to cultivate as responsible citizens (Zeidler, 2014). More recently, STEAM education, with the addition of the arts to STEM subjects, has emerged as a new approach to improve students' creative thinking skills, engagement, innovation, and problem-solving skills and other cognitive benefits (Colucci-Gray et al., 2017; Quigley et al., 2017).

Curriculum integration is aimed towards making the curriculum more relevant to real-life experiences and issues "with less concern for delineating disciplinary boundaries around kinds of learning." (Gehrke, 1998, p. 248) Although efforts have been made to support individual teachers to 
integrate subjects in their classroom practices (e.g., Quigley \& Herro, 2016), there is currently little empirical research on collaborations of teachers across different subjects, which can be because such cross-subject collaboration does not frequently happen in schools (Johnson, 2003), particularly among subjects that are traditionally considered disparate as in the case of STEM and history. Research has indicated that there is not much space for communication between teachers of different subjects due to school structures (Al Salami et al., 2017; Lesseig et al., 2016). To understand the affordances and potential challenges of cross-curricular curriculum integration, it is crucial to examine how subjects can be integrated in the curriculum and for what educational purposes. For example, what are some ways STEM subjects and arts/humanities subjects can mutually enrich each other? What goals of arts and humanities subjects can be supported by infusing STEM subjects in the curriculum, and vice versa? What are the potential benefits of integrating STEM and arts/humanities subjects in the curriculum compared to addressing them separately?

In this study, we address these questions by looking into curriculum materials developed by teacher teams, each consisting of teachers from multiple school subjects. Our particular interest is in the use of history in STEAM curricula, given the nature of history as an effort to make sense of people, ideas, events, and places of the past and explain the unfolding of change (Maza, 2017). All human activity, including the practices of STEM, is historically and culturally situated (Medin \& Bang, 2014). Not only is understanding the history of ideas and concepts crucial in deep learning in STEM, but the learning of history can be enriched by considering the context of STEM in each historical period. For example, a nuanced understanding of Newtonian mechanics would entail a grasp of how knowledge of mechanics has evolved since Aristotle's and Descartes' time, since this historical background provides the context necessary for appreciating the innovations in Newton's work. Likewise, for a high level of understanding of the Renaissance, some knowledge of Copernican and Newtonian science would be indispensable, considering the crucial role of modern scientific discoveries and ways of thinking in characterizing the period. Similarly, learning about the mathematical techniques described in ancient Chinese books can both enhance students' mathematical understandings and broaden their historical knowledge (Park \& Song, 2021). These examples are suggestive of the benefits of integrating history and STEM subjects in facilitating students' rich understanding of subject knowledge. Further examples showing the benefits of the integration will be presented and discussed later in this paper.

To consider how these benefits can unfold in integrated curricula, we focus on the learning goals presented in the cross-subject STEAM curricula developed by teacher teams.
Given the centrality of learning goals in instructional practice (Anderson \& Krathwohl, 2001), the focus on learning goals will allow exploring the possible roles that history can play in facilitating STEAM learning. This way, the findings will shed light on future research and practice in both STEM education and history (and broader arts and humanities) education. To this aim, our research question was: What historyrelated learning goals are presented in the STEAM curricula developed by cross-subject teams of high school teachers?

\section{Literature review}

\section{Curriculum integration and STEAM}

During the past decades, increasing attention to the role of interdisciplinarity in knowledge production (Cartwright, 1999) has inspired educators to address curriculum topics from more than one disciplinary perspective to enrich student learning (Drake \& Burns, 2004). Integrated curriculum has been advocated on the grounds that real-life, complex problems cannot often be resolved by approaches based on a single discipline (Eurydice, 2011). After the early ideas on bringing different school subjects together in the late 1980s and early 1990s (Drake, 2007), there has been a recent resurgence of interest in the integrated and interdisciplinary curriculum in parallel with the focus on 21 st-century skills and creativity (Drake \& Reid, 2018; Henriksen et al., 2016). According to Beane (1997), curriculum integration can be characterized in broadly four terms: (a) organization of the curriculum around real-world issues and problems relevant to students; (b) planning of learning experiences to integrate pertinent subject knowledge; (c) use of knowledge to address the central issue rather than learning in subjects; and (d) application of knowledge through substantive problem-solving activities and projects. Although the interest in integrated curriculum waned in some countries with the increasing accountability pressure (Marsh \& Willis, 2007), it has exerted sustained influence on policies in East Asian countries such as Singapore (Lam et al., 2013) and particularly Korea, where the government has provided a significant amount of funding to promote STEAM curriculum and professional development of teachers (Hong, 2017).

In recent years, STEAM, with "arts" added to STEM, has drawn much attention from educators as a useful approach to curriculum integration (De la Garza \& Travis, 2019; Khine \& Areepattamannil, 2018). As Peppler and Wohlwend (2018) stated, "The promise of STEAM approaches is that, by coupling STEM and the arts, new understandings and artifacts emerge that transcend either discipline" (p. 88). Among the components of STEAM, the meaning and scope of the "A" have been problematized by several authors (ColucciGray et al., 2019; Erduran, Guilfoyle \& Park, in press). 
Following Ge et al. (2015), we consider STEAM as a broad concept that encompasses liberal arts, social studies, and humanities. Given this background, it can be said that current literature in STEAM education is mostly concentrated on the integration of "narrow arts" (i.e., visual and performing arts), while the broader humanities subjects such as history are underrepresented. In this view, considering the benefits of integrating humanities subjects into STEM becomes an important task (Spector, 2015).

\section{History and STEM learning}

The educational value of history has not only been recognized within humanities and social studies education but also in the context of STEM education. One prominent approach to the integration of STEM and history is through the use of the history of science and technology. For example, science educators have long been keen on infusing history of science in school science. Matthews (2014) suggested that including a historical component in science teaching can promote conceptual understanding of science, understand the nature of science, and make science less abstract and more engaging. Moreover, he noted the potential of history for "connections to be made within topics and disciplines of science, as well as with other academic disciplines; history displays the integrative and interdependent nature of human achievements." (p. 107) Matthews uses the example of Galileo's physics to demonstrate the interrelation of school subjects in the history of science: Galileo's theory was based on Euclidean geometry, technological advances such as lens grinding and the telescope, his theological views that freed him to investigate the phenomenon in the heavens as well as on the earth, and patronage, commerce and other social factors (Matthews, 2014).

History of science is also commonly used to teach the nature of science such as the epistemic and social aspects of science (Allchin et al., 2014). To this end, science educators often use specific episodes in the history of science to facilitate science learning (Allchin et al., 1999; Matthews, 2005; Vilani \& Arruda, 1998). Similar efforts have also been made in mathematics (Fauvel, 1991; Fried, 2014; Furinghetti et al., 2012) and technology (Hallstrom \& Gyberg, 2009; Lee, 2018) education. Besides using history for conceptual learning in STEM, some authors have used historical figures in science to cultivate students' interest in and attitudes towards science. Hadzigeorgiou et al. (2012) used the story of Nikola Tesla who popularized alternating current after a long 'war of the currents'. They found that reading and reflecting on the story can have a positive impact on students' conceptual understanding of alternating current and helped them develop ideas in the human aspects of science, heroic qualities, the limits of human experience, a sense of wonder, and challenges to conventions.
More recently, history of science has been also advocated for decolonizing the science curriculum by challenging the Eurocentric conception of science and instead highlighting the contributions of non-European traditions in the formation of modern science (Gandolfi, 2021; Park \& Song, 2021). Gandolfi (2021) utilized the concept of global history of science to develop and implement lessons highlighting the significant role of intercultural exchanges in shaping scientific knowledge. These examples show that the intersection of STEM and history can not only serve as a fruitful source of deeper learning in both domains but also contribute to the broader goal of social justice in education (Yacoubian \& Hansson, 2020). Despite these benefits, however, several authors have cautioned against the 'biased' uses of history in STEM education. For example, Allchin (2000) claimed that selective history can convey misleading images about science and scientists such as the simplistic idea that scientific investigations follow a linear, 'cookbook' process, which leads to obscuring the social dimension of scientific practice.

\section{Theoretical framework: Four fundamental purposes of history learning}

To understand how the purposes of history learning can manifest in STEAM curricula, we use the four purposes of history education proposed by Barton and Levstik (2004) as a theoretical lens. In their framework, it is asserted that the central goal of history learning is cultivating democratic citizenship and the common good rather than imparting mimicry of academic history (Barton \& Levstik, 2004). Given that STEAM similarly aims to embrace social inclusion, community participation and sustainability issues through the inclusion of arts (Colucci-Gray et al., 2019), Barton and Levstik's approach can be useful for exploring a synergistic relationship between history and other disciplines that constitute STEAM. Based on the democratic conception of history education, its four purposes were accordingly suggested-identification, analysis, moral response, and exhibition (Barton \& Levstik, 2004).

\section{Identification}

Through learning history, students are expected to build connections between themselves and the events and people in the past (Barton \& Levstik, 2004), which makes several types of identification particularly important. First, identification can occur within the context of personal and family history. According to Barton and Levstik (2004), however, the most prominent mode of identification is to identify oneself as a member of a nation as "imagined political communities" (Anderson, 1983; Bell, 2003; Yuen \& Byram, 2007). Considering that democratic participation necessitates 
individuals' attachment to their country, national identification is central to establishing "the state's continued legitimacy and for our own sense of political belonging." (p. 59) However, they also point out the downside of emphasizing identification. When we link ourselves to one family, community or nation, Barton and Levstik argue, it often leads to cutting ourselves off from others who do not belong to the same group. Also, there is the danger of regarding one's own group and country as morally superior and inherently good compared to others, which is found in approaches to history education as a means to inculcate patriotism in young people (Barton \& Levstik, 2004). Identification goals are not often found in the science curriculum, which may be due to the universality of scientific knowledge that prevailed science education for a long time (Cobern \& Loving, 2001). However, recent studies focusing on culturally relevant science teaching shed light on the issue of identification in the context of science and STEM education. For example, Park and Song (2021) taught East Asian traditional science to Korean preservice science teachers and investigated how they negotiated their identities as a science teacher and East Asian person while learning about "our science" and "our history," pointing to the potential role of identification and multiple identities in STEM education.

\section{Analysis}

The cultivation of students' analytical skills in history has been advocated by historians and educators across different education systems (Rouet et al., 1996; Spoehr \& Spoehr, 1994; van Drie \& van Boxtel, 2008). Historical analysis involves the consideration of developmental trends, argumentative structures, and causal patterns in history (Barton \& Levstik, 2004). This stance highlights learning about how historical research is conducted by asking questions, collecting resources and artifacts, and analyzing them to construct knowledge about the past. By engaging in historical analysis and inquiry, students are expected to grasp how the decisions of the past have shaped current status and what lessons can be learned from history (Barton \& Levstik, 2004). This analytic goal of history learning is frequently presented as a core element of contemporary history curricula (De Groot-Reuvekamp et al., 2014) and broadly aligns with the growing attention to historical literacy, historical thinking and historical reasoning (Kuhn et al., 1994; Lee, 2007; van Drie \& van Boxtel, 2008). Historical analysis consists of a grasp of historical knowledge (e.g., historical significance, periodization, narrative, historical information), evaluation of evidence (e.g., sourcing, corroboration, contextualization), and use of evidence (e.g., claims, evidence, coherence) (Breakstone, 2014). In science and STEM education research, there has been sustained research interest in teaching scientific argumentation, or the justification of claims based on evidence and reasoning (Erduran \& Jiménez-Aleixandre, 2007), which can be meaningfully linked to historical analysis. The similarities between scientific and historical argumentation aligns with the view of some analytic philosophers who emphasized the empirical and scientific status of historical knowledge (Hempel, 1942; Nagel, 1961). Hence, the analytic goal of history can be useful for connecting STEM and history in the curriculum.

\section{Moral response}

Another important goal of history learning is to call up moral responses to historical events and people (Barton \& Levstik, 2004). We admire, condemn, remember and forget people based on the standards of right or wrong, evaluate what should and should not happen, which is essential for making decisions in participatory democracy (Barton \& Levstik, 2004). Such moralizing function of history learning is often associated with the use of heroes. By referring to a historical figure as a hero, they represent how people should be (Barton \& Levstik, 2004). At the same time, Barton and Levstik caution against idolizing historical figures and suggests that we stay open to heroes' flaws as well as their achievements. This way, they suggest that the focus should be more on heroic acts than heroes themselves (Barotn \& Levstik, 2004). Another frequent moralizing goal presented in history curricula is patriotism, although the legitimacy of such a goal has been debated (Carretero, 2011; Merry, 2009). Merry (2009) asserted that an overemphasis on the affinity to one's nation and homeland might lead to a myopic understanding of history and a sense of superiority relative to other nations and cultures. These goals are closely related to the arguments for moral development through STEM education, particularly by engaging in socioscientific issues, which often poses moral and ethical dilemmas (Sadler, 2004). Zeidler and Keefer (2003) argued that at the heard of socioscientific issues education is "the consideration of ethical issues and construction of moral judgments about scientific topics via social interaction and discourse" (p. 8). In this regard, the incorporation of history in STEAM education can offer a useful way to investigate not only the technical aspects of real-world issues but consider them more holistically along with the moral and ethical aspects.

\section{Exhibition}

By teaching history, we expect students to be able to display their historical knowledge and skills in their interactions with other people in society. When students display their understandings of history to peers or acquire their historical knowledge from another person's display through books, movies, museum visits, artworks, or casual interactions, these activities involve some form of exhibition in service 
of others. Barton and Levstik (2004) consider exhibition as an essential function of history learning because it is most likely to contribute to participatory democracy and. In the classroom, students can express their historical knowledge through creating posters, videos, and plays and use them to display their understandings for peers as well as others inside and outside the school (Barton \& Lesvstik, 2004). To do this, they note, considering the needs and interests of the prospective audience is of crucial importance. Given the focus of STEAM on promoting creativity by incorporating arts and helping children express their STEM learning (Bequette \& Bequette, 2012; Sharapan, 2012), the exhibitive goal of history has potential to benefit from integration with STEM subjects.

\section{Summary}

The literature review and the theoretical framework suggest that history and STEM have several overlapping goals which can be further developed through the lens of STEAM. The intersection of history and STEM, however, have been investigated mainly in the context of using history of science in science education, whereas the affordances of integrations in the broader context of STEAM have yet to be explored. Meanwhile, the four purposes of history learning as conceptualized by Barton and Levstik (2004) help to consider how STEM and history can enrich each other to facilitate transdisciplinary learning. From the literature, we can identify potentially fruitful ways in which the four purposes of history learning can overlap and interact with research areas in STEM education (e.g., culturally relevant science education, scientific argumentation, socioscientific issues and creativity).

\section{Methods}

\section{Context and sample selection}

STEAM lesson materials were identified and collected from the Korea Foundation for the Advancement of Science and Creativity's (KOFAC) STEAM website (https://steam. kofac.re.kr/). KOFAC is a quasi-governmental, non-profit organization that aims to "promote a culture that champions science and create an educational system that cultivates creative talents" (KOFAC, n.d.). As part of its initiative to promote STEAM in schools, KOFAC has funded interdisciplinary teacher teams at Korean elementary, middle, and high schools for developing and implementing STEAM curricula since 2011. Each teacher team designed a STEAM curriculum around a specific interdisciplinary topic of their choice, which was then implemented with students and publicized on the website. For the present study, a subset of the lesson plans was used for analysis following a selection process. First, given our focus on the role of history, we selected the curricula where history was included as a constituent subject either by including at least one history teacher in the team and/or explicitly referring to learning goals in history. Second, considering that the structure of the lesson plans varied depending on the year they were developed, we focused on the curricula developed during 2018-2019 to ensure consistency in the structure of the lesson materials. Third, we only included STEAM curricula for high school students to focus on the integration of STEAM at the upper secondary level. It should be noted that these curriculum documents were developed by teachers participating in a KOFAC grant scheme and therefore are not representative of the involved schools' or teachers' educational practices in general, although we refer to each curriculum as "School X's curriculum" for simplicity of presentation.

From 460 high school STEAM curriculum materials published on the STEAM website during the 2 years, 18 were identified as inclusive of history. After the initial screening, we excluded five curricula where the inclusion of history was superficial (i.e., no history-related learning goals were made explicit) or the data was incomplete (i.e., the lesson plan was not sufficiently detailed for analysis). Applying these selection criteria yielded 13 curricula (each developed by a unique teacher team) that amounted to STEAM lesson plans for $133 \mathrm{~h}$ of lessons. Figure 1 describes the locations of the 13 schools, each of which a teacher team developed one STEAM curriculum. As seen in the map, the schools were located across South Korea in both urban and rural regions. Each team's curriculum material was provided in one PDF file that collated the background, curriculum design process, lesson plan, student data from classroom implementation, and teacher reflections and suggestions. Our primary interest was the STEAM lesson plan, and other sections in the documents were used to supplement and nuance the lesson plan data. The length of the documents spanned between 17 to 114 pages, and a total of 649 pages of documents were subjected to content analysis. Table 1 includes information about (a) how many of the 13 teams included teachers of each subject (e.g., All 13 teams included at least one science teacher in the team) and (b) the number of teachers of each subject across all 13 teams.

\section{Data analysis}

To understand to what extent and how history-related learning goals were presented in the STEAM curricula, we coded each of the 13 curriculum materials qualitatively and then analyzed them collectively using the constant comparison method to identify patterns in the data (Taylor \& Bogdan, 1998). This way, the study was designed as a single case study with 13 embedded units to understand how the 


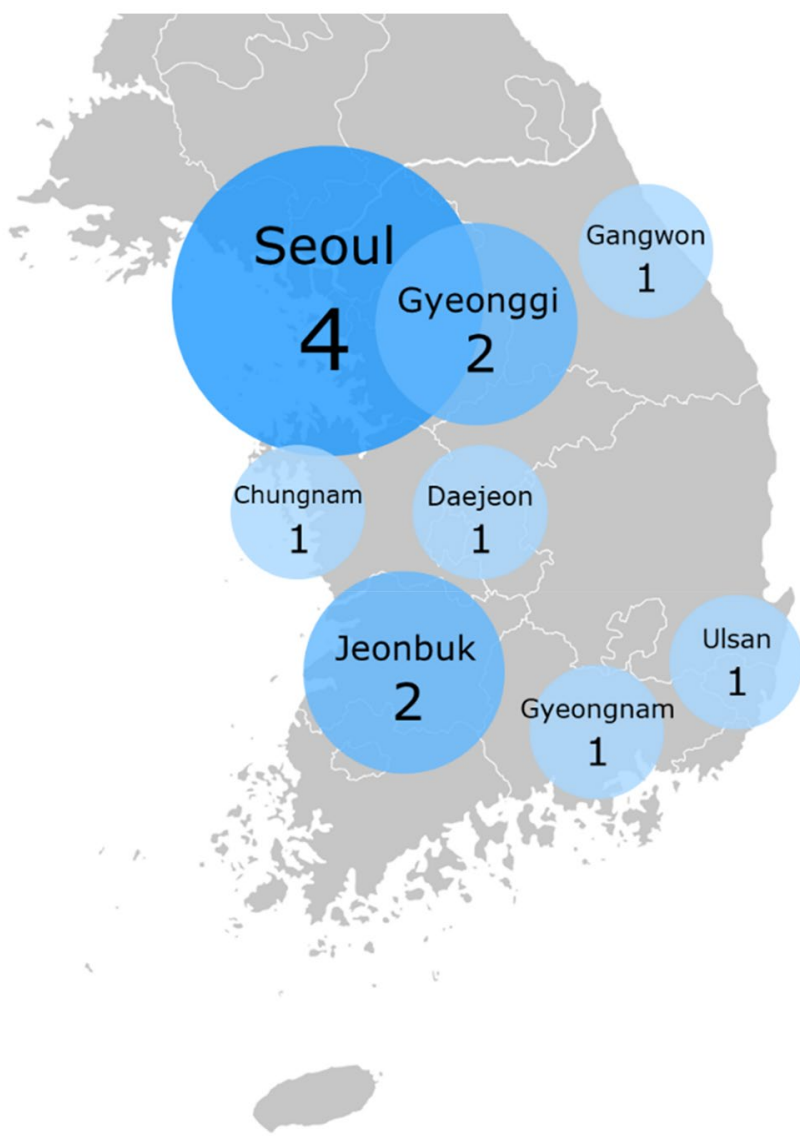

Fig. 1 Location of the schools

Table 1 Frequency of subjects involved in STEAM curricula and number of teachers

\begin{tabular}{lrc}
\hline Subject & Frequency (\%) & $\begin{array}{l}\text { Number of } \\
\text { teachers }\end{array}$ \\
\hline Science & $13(100 \%)$ & 27 \\
History & $12(92 \%)$ & 13 \\
Math & $9(69 \%)$ & 16 \\
Social studies & $5(38 \%)$ & 5 \\
Language and literature & $4(30 \%)$ & 8 \\
Geography & $3(23 \%)$ & 3 \\
Technology & $2(15 \%)$ & 2 \\
Art & $2(15 \%)$ & 2 \\
PE & $1(7 \%)$ & 1 \\
Health & $1(7 \%)$ & 1 \\
Career & $1(7 \%)$ & 1 \\
Unidentified & & 5 \\
Total & & 84 \\
\hline
\end{tabular}

history-related goals unfold in the STEAM curriculum documents. Specifically, the embedded units were the teacher teams and the single case in focus was the KOFAC funded high school Korean teachers 2018-2019 cohort that used history integration in the STEAM curriculum.

Drawing on Barton and Levstik's (2004) four purposes of history learning, we used both literature-driven and empirically emergent codes. The unit of analysis was a statement in the documents where the learning goal of the whole curriculum or individual lessons was expressed. To ensure the validity and reliability of the analysis, two authors independently read through each curriculum and coded segments relevant to the research question. Each occurrence of learning goals related to history was coded into one of the four categories (identification, analysis, moral response, and exhibition) as well as descriptive codes that capture the specific nuance in which history is used in the curriculum. For example, the statement that "From a historical point of view, solutions to the problems that the humans living in the present are faced with can be found in history" found in School B's curriculum was coded as "analytical" (theory-driven code) and "learning from the past" (inductive code). This coding process allowed constructing subcategories within each of the four purposes being developed. The two coders then met three times to discuss any ambiguities in coding to refine coding criteria and reach an agreement. Once the coding was completed, the 13 cases were then compared to develop descriptive themes. This comparison involved examining the frequency of categories and codes presented in the curricula and identifying qualitative patterns by comparing, contrasting and clustering different cases (Yin, 2017). Since the analyzed documents included not only the lesson plans but also instructional materials (e.g., PowerPoint slides, worksheets), teacher materials, assessment criteria, and teachers' reflections, these additional information was used to supplement the analysis and ensure trustworthiness of interpretation. For example, the instructions in teacher materials often allowed for a clear understanding of the curriculum goals in the lesson plans.

\section{Findings}

Table 2 summarizes the content of the 13 STEAM curricula developed by teacher teams. The qualitative analysis led to characterizing the types of history-related learning goals and how they are presented in relation to STEM. In the following, we illustrate our findings with respect to the four purposes of history learning, with illustrative examples.

Overall, our findings point to several major ways in which the goals of history learning can interact with those of STEM learning. In the meantime, there were several discernible patterns in the use of history in STEAM curricula that emerged from the analysis. First, the majority of curricula aimed for identification between the learner and their regional and national histories. Second, all curricula 


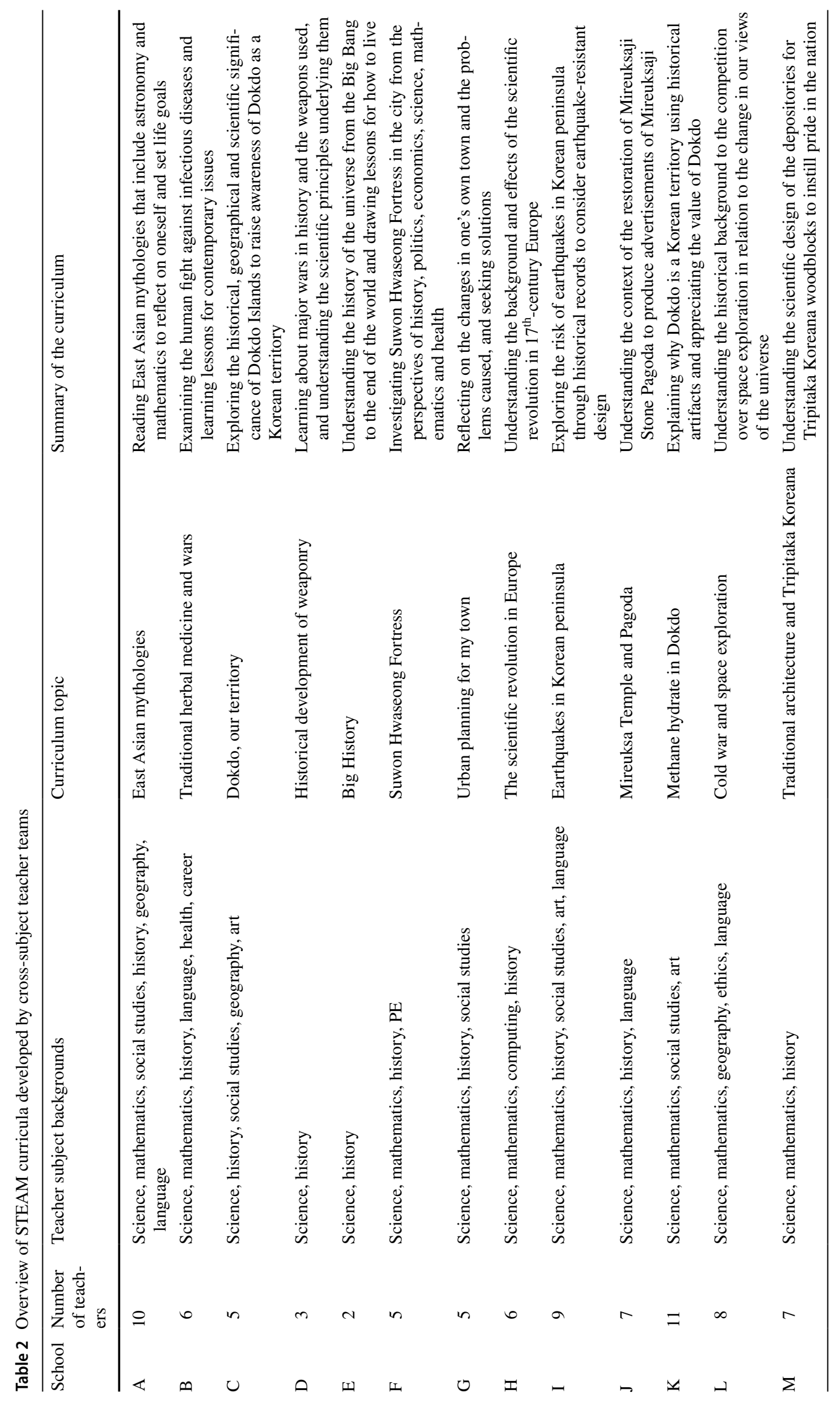


included goals related to historical analysis skills, sometimes integrated with scientific inquiry. Third, the STEAM curricula were aimed at eliciting students' moral response to history, particularly when the main content relates to issues at the national level. Fourth, the integration of subjects provided opportunities for exhibiting learners' historical understanding through various activities and in various representational formats.

\section{Identification goals}

Learning goals related to identifying oneself with their personal history, history of their community and nation was found in ten curricula (Table 3). Among the ten curricula where identification goals were present, seven $(70 \%)$ of these curricula were focused on community (i.e., district, city, province) and nation-level identification, which resonates with place-based learning STEM education, characterized as "a situated, context-rich, transdisciplinary teaching and learning modality distinguished by its unequivocal relationship to place, which is any locality that people have imbued with meanings and personal attachments through actual or vicarious experiences" (Semken et al., 2017, p. 542). Besides, identification as a curriculum goal appeared only when the main topic of the curriculum covered areas equivalent to or smaller than a nation; for curricula focused on an topics that exceed Korean or East Asian boundaries (e.g., history of diseases, the scientific revolution, history of weapons), identification was not targeted as a goal. For example, School H used the topic of the scientific revolution in Europe, a historical event with little relevance to Korean high school students' identity, from which no identification goals were found. The only exception to this was School E's curriculum that used the Big History approach, as detailed below.

\section{Identification with personal and community histories}

The goal of identification with personal history was found in School G's curriculum, where students were asked to "discuss the changes in one's living space, how these changes impacted them, and how it relates to the advancement of science," representing the identification of one's present self and personal history. The community-level identification was found in three curricula, particularly when the theme of the curriculum concerned a historical site within the region. For example, a central topic of School F was Suwon Hwaseong Fortress located near the school, with a consideration that the fortress would be "accessible for students." Within such a regional context, the curriculum explored not only the cultural and political aspects related to the fortress but also the mathematical and engineering principles that helped to build the fortress in the late nineteenth century. Similarly, School J's curriculum was contextualized within Mireuksa
Table 3 Presentation of history-related goals in STEAM curricula

\begin{tabular}{|c|c|c|c|}
\hline Category & Goal & Frequency & Subtotal \\
\hline \multirow[t]{5}{*}{ Identification } & Personal & 1 & 11 \\
\hline & Community & 3 & \\
\hline & National & 5 & \\
\hline & Supranational & 1 & \\
\hline & Universal & 1 & \\
\hline \multirow[t]{6}{*}{ Analytic } & Working with primary sources & 7 & 32 \\
\hline & $\begin{array}{l}\text { Explaining causation, process, comparison, and } \\
\text { arguments }\end{array}$ & 9 & \\
\hline & Contexutalizing historical events & 5 & \\
\hline & Examining science and technology of the past & 6 & \\
\hline & Learning about the nature of science & 1 & \\
\hline & Learning lessons from history & 4 & \\
\hline \multirow[t]{5}{*}{ Moral response } & National pride & 1 & 7 \\
\hline & Care for disputed territories & 2 & \\
\hline & Ethics & 1 & \\
\hline & Admiration of historical figures & 2 & \\
\hline & Critical evaluation of historical figures & 1 & \\
\hline \multirow[t]{4}{*}{ Exhibition } & Explanatory exhibition (scientific) & 1 & 14 \\
\hline & Explanatory exhibition (historical & 8 & \\
\hline & Persuasive exhibition & 3 & \\
\hline & Imaginative exhibition & 2 & \\
\hline Total & & & 64 \\
\hline
\end{tabular}


site and Mireuksaji Stone Pagoda (the largest Buddhist temple in the ancient Korean kingdom of Baekje) in the region. The curriculum was aimed at understanding the historical and scientific backgrounds of Mireuksa and "discuss the value of Mireuksa in our region." This statement reflects the team's intention to promote students' regional identity which is distinguished from personal or national identity.

\section{Identification with national history}

Among the 13 developed curricula, four featured this level of identification by facilitating the connection between the learner and Korean history. Such goals were made apparent by using expressions such as "our," "ancestors," and "forefathers" in the learning goals. Referring to the learning goal of "recognizing the past in relation to the present," School I designed an activity where students investigate historical records of earthquakes in the Korean peninsula and the technologies that ancestors used to build earthquake-resistant buildings. From this activity, the lesson goal was to "understand the wisdom of ancestors and consider the technologies needed for safe Korea." Similarly, School M used a case study of Tripitaka Koreana (wooden printing blocks from the thirteenth century) from scientific, geographical and historical viewpoints, with the aim to "understand the excellence of science and technology that ancestors achieved" and to "succeed and further develop such an outstanding tradition and have pride in it." Common to these two curricula was that they both presented the aim of cultivating the learner's national identity by appreciating the excellence of science and technology that our national ancestors possessed.

The other two curricula with national identification goals featured the Liancourt Rocks dispute (a territorial dispute between South Korea and Japan) as the overarching topic of the curriculum. School C and School K's STEAM curricula focused on examining the historical evidence supporting South Korea's sovereignty of the islands (referred to as Dokdo in South Korea), and appreciating the geopolitical and scientific value of Dokdo. By "understanding the meaning of territory" and "seeking ways to promote our sovereignty of Dokdo," the curriculum ultimately aimed to "cultivate an appropriate view of history and a sense of sovereignty." These two examples suggest that STEAM curricula focused on disputed territories, by distinguishing "us" and "them," can be used as a powerful tool to encourage individuals to build their identity within the context of national history.

\section{Identification with units larger than nations}

Interestingly, two more levels of identification-besides the personal, community and national-level identification proposed by Barton and Levstik (2004)—were found in the curricula. In School A's case, the main topic of the curriculum was Chinese mythology classics such as Classics of Mountains and Seas, Verses of Chu, and Huainanzi. Based on the reading of these mythologies that were grounded on ancient Chinese cosmology, the curriculum goal was to "reflect on one's identity and set one's life goals" through the examination of ancient East Asian mythologies. In particular, the curriculum linked the mythologies to the learning of astronomy, particularly understanding the constellations and celestial motions observed in different regions. It stated that "our youths' habits of reading are biased towards Western mythologies such as those of Greece and Rome" to argue for attention to "Eastern" mythologies. This statement entails an identification as the "East" as opposed to the West, which is a higher unit for identification for Korean students than the nation.

School E's curriculum went a step further to identify the individual within the history of the universe, employing the idea of Big History (Table 4). Big History refers to an approach to history that "seeks to understand the integrated history of the cosmos, earth, life, and humanity, using the best available empirical evidence and scholarly methods" (IBHA, 2021) and has been popularized by historian David Christian since the 1990s. School E's curriculum stated as its aim that students "understand that the histories of the Earth and life are part of the history of the universe" by learning about how the universe was created by the Big Bang and evolved to the present. Specifically, this curriculum capitalized on the concept of "thresholds" to draw analogies

Table 4 Outline of School E's lesson plan based on the Big History approach (excerpt)

\begin{tabular}{lll}
\hline Week & Learning goals & Format \\
\hline 1 & $\begin{array}{l}\text { Understand the concepts of ingredients, conditions and thresholds by looking at world history through Big } \\
\text { History }\end{array}$ & Lecture \\
2 & $\begin{array}{l}\text { Understand the process in which the solar system was formed and the ingredients that led to the thresh- } \\
\text { olds }\end{array}$ & Lecture, student participation \\
3 & Understand the actual size of the solar system compared to our usual perceptions about it & Group activity \\
4 & $\begin{array}{l}\text { Identify the ingredients that evoked the new threshold from the birth of first humankinds to the start of } \\
\text { agriculture }\end{array}$ & Lecture, inquiry activity \\
5 & Write what kind of ingredients should be prepared in one's own life, using the concept of threshold & Activity \\
\hline
\end{tabular}


between natural history and human lives. As shown in Fig. 1, School E's curriculum points to one potentially fruitful way in which the integration of history and STEM subjects can fertilize each other. In infusing history, this curriculum transcended the traditional boundary of "nations" in history but instead sought how major events in the history of the universe can promote students' scientific and historical understanding.

\section{Analytic goals}

Analytic goals were the most common among the four purposes of history (Table 3). Five of the thirteen schools included at least four types of analytic goals, and the rest included at least one goal related to historical analysis. There were six major ways in which analytic goals were manifested in the STEAM curricula. Most prominently, nearly half of the curricula included professional historical research where students were engaged in activities using primary sources. While the majority of the curricula were aimed at analyzing historical narratives and historical contexts, there were some cases that considered STEM knowledge and practice in the past. Furthermore, several curricula included learning goals to derive lessons from history.

\section{Working with primary sources}

Historical research starts from analyzing primary sources. Seven schools (54\%) designed the curriculum for students to analyze historical sources. The types of sources included both documentary and non-documentary objects. This goal was often manifested by encouraging students' engagement in historical research as part of STEAM learning. School I's curriculum on earthquakes and safety is an excellent example. As shown in Table 5, the teacher instructed students to look for primary sources and journal articles online, instead of providing the information as a handout. By doing so, the use of both primary sources and secondary literature allowed the students to "understand the motivations of past people for building disaster-safe buildings." There were other curricula that focused on the analysis of nondocumentary sources. School F's curriculum included an activity to investigate the structure of the Suwon Hwaseong Fortress through visual observation, in a field trip or studying pictures, instead of reading document sources. School D also designed an object-based study by taking weaponry as a source for studying technological advances in the history of warfare. These examples illustrate how engagement in scientific analysis of historical sources can simultaneously serve the aims of science education (i.e., developing scientific inquiry skills) and those of history education (i.e., learning how historical knowledge is constructed).

\section{Explaining causation, process, comparison, arguments}

Nine curricula (69\%) presented goals related to analyzing historical narratives, that is, the construction of historical stories. This goal appeared most frequently among the analytic goals, in turn suggesting the potential usefulness of historical narratives in promoting analytic thinking. This category consisted of explaining causal relations, explaining process and change, making comparisons and contrasts, and constructing historical arguments. School L noticeably designed a curriculum targeted for explaining causal relations, with the aim of understanding the correlation between the Cold War and the space competition. Similarly, School D's curriculum was designed to cultivate students' understanding of "the socio-cultural background to the scientific changes and what these changes meant for the general society in history." The goal was to first explain the relationship between disease and the Imjin War (a war between Korea and Japan, 1592-1598), and then to compare this case with

Table 5 Outline of School I's lesson plan on earthquakes in Korean history (excerpt)

\begin{tabular}{|c|c|c|}
\hline Phase & Instructional activities & Notes \\
\hline Introduction (5 min) & $\begin{array}{l}\text { Teacher shows a news video clip about Gyeongju earthquake damages and asks: Is the Korean } \\
\text { peninsula safe from earthquakes? } \\
\text { - Encourage students to consider that Korea was historically unsafe from earthquakes and to } \\
\text { question how Korea could cope with the earthquakes }\end{array}$ & \\
\hline Development (145 min) & $\begin{array}{l}\text { Students work in groups of four for the research (each taking different roles) and create a shared } \\
\text { document } \\
\text { - Encourage students to use primary sources from an online database. Give step-by-step instruc- } \\
\text { tions on how to search and read primary sources on the website } \\
\text { - Encourage students to use published articles as references } \\
\text { - Encourage students to use Google Docs to work together simultaneously } \\
\text { Students create presentations } \\
\text { - Encourage students to construct the presentation with simple words and images }\end{array}$ & $\begin{array}{l}\text { Takes place in } \\
\text { the computer } \\
\text { room } \\
\text { Registration } \\
\text { needed for the } \\
\text { website }\end{array}$ \\
\hline Wrapping up (50 min) & $\begin{array}{l}\text { Students share their presentations about earthquake-proof engineering in cultural heritage sites } \\
\text { Teacher summarizes the class }\end{array}$ & \\
\hline
\end{tabular}


disease outbreaks during the Crusades, the Crimean War, and the Russo-Japanese War. This case shows how events in different historical periods and geographical areas can be linked through the use of a STEM theme such as infectious diseases. Two curricula, each from School C and School K, presented goals for students to construct historical reasoning and arguments. Both curricula focused on the history of the Dokdo Island, a politically disputed territory between Korea and Japan. The aim was to equip students with supporting historical evidence in making an argument that the Dokdo Island has been, historically, a Korean possession.

\section{Contextualizing historical events}

Five of the STEAM curricula (38\%) aimed to promote students' skills in contextualizing historical events by situating a given topic in the wider political, socio-economical, and cultural backgrounds. School D's curriculum presented a good example by connecting history of war and history of science. Its curriculum goals included "understanding the history and background of major wars in each period" and "understanding when, where, and through what process scientific events or changes occurred." With these understandings, the curriculum aimed to "build the capacity to consider what these scientific events meant to wider society." In another case, School H's curriculum included a learning goal of understanding the Renaissance as the background for the scientific revolution. Based on the idea that "the emergence of scientific theories is closely related to its historical context," they targeted to explain that the growth of academic culture during Renaissance facilitated the scientific revolution in the following years. From these examples, we can see that STEAM can be an effective tool for appreciating the historical events not merely as singular, isolated events but as situated within the broader cultural context including STEM.

\section{Examining science and technology of the past}

Six curricula (46\%) included the goal of examining STEM in history. Activities in most curricula were aimed at either examining the human understanding of nature that existed at a certain time in the past and how they evolved over time or using the lens of modern science to reappreciate the value of traditional STEM knowledge. School L is a good example of the first type of goal. In order to "historically study the cosmology of each time period," their learning goals included "learn about the scientific revolution in the sixteenth and seventeenth centuries and study the theories of Copernicus, Kepler, Galilei, and Newton." School M's activities adopted modern science as a lens to look into the science of the past.
In studying their topic, Tripitaka Koreana, one of their goals was to experiment Bernoulli's theorem to understand the scientific principles used to build the depositories for the Tripitaka. Both School L and School M's curricula show how the consideration of STEM can enrich students' understanding of history and vice versa.

\section{Learning about the nature of science}

School D's curriculum presented another distinctive kind of analytic goal, namely, to understand the nature of science through history of science. Nature of science refers to the epistemic and social characters of science (Erduran \& Dagher, 2014) and has gained much attention from STEM educators in recent decades (Park et al., 2020; Pleasants, 2020). School D's curriculum goal was to "understand the nature of science and its social characteristics through studying the history of science" and to "understand the relationships between science, technology, and society." It is notable that they used the specific topics of warfare and weaponry to highlight different aspects of nature of science. Although nature of science typically encompasses both epistemic (e.g., aims and methods of science) and social (e.g., cultural and political influence on science) features of science (Erduran \& Dagher, 2014), School D's learning goals were focused on the latter kind, due to its focus on warfare.

\section{Learning lessons from history}

The last type of analytic goals was to learn lessons from history. The role of history in searching for generalizations and, thus, guiding present actions and decisions have been asserted as a central function of history learning, although the risk of misguided and hasty generalizations is recognized (Bartin \& Levstik, 2004). Four schools (31\%) were keen to encourage their students to reflect on the history in making sense of the contemporary world. School B's curriculum explicitly stated that they incorporated history in the STEAM curricula because "the solution to numerous problems of humanity can be found in history." School A took their inspiration from East Asian mythologies, given that mythologies "describe the origin of the world, humans and cultures ... thereby provides the foundations of current societies and institutions." Their goal of allowing students to reflect on the present based on the ancient mythologies epitomizes the general idea of "look[ing] into the past for some suggestions as to the likely consequences of actions at the societal level" in history learning (Barton \& Levstik, 2004, p. 76). 


\section{Moral response goals}

Across the 13 curricula, seven presented moralizing goals (Table 3). Two cases were concerned with historical figures, either to evoke admiration or critical evaluation of the person in question. School F's curriculum spotlighted two historical figures, Jeongjo of Joseon and Jeong Yakyong, who promoted science and engineering that led to the construction of Suwon Hwaseong Fortress. On the contrary, School H's curriculum included an activity to consider Issac Newton's scientific life critically. In the context of the scientific revolution in Europe in the seventeenth century, it first outlined Newton's scientific contributions such as calculus and the law of universal gravitation. It then turned to describing Newton's religious and occult studies and asked students to discuss whether we can view Newton "as a pioneer in the age of reason or the last of the magicians." This activity engaged students in a critical appraisal of a historical figure in science, pointing to contrasting aspects of Newton's life and work.

The objects of moral response were not limited to humans. In the curricula that were organized around national issues, moralizing functions were often coupled with national identification and manifested in the forms of national pride, or love and care for territory. School M's curriculum aimed at "instilling in students pride in the standing of Korea in today's world." To this aim, it started from presenting the science and technology used for storing Tripitaka Koreana as something to be proud of, and the fact that such excellence was "acknowledged internationally by its inscription in UNESCO Memory of the World Register." A similar moralizing goal was apparent in School C's curriculum, where "care and love for Dokdo" were presented as the primary curriculum goal. These findings are reminiscent of several observations that history educators have made about school history in East Asian countries. It has been argued that in East Asian curricula, history is often "not an academic subject but a moral discipline that trains people to become righteous" (Tohmatsu, 2011) in service of developing national identity (Baildon \& Afandi, 2018). Learning goals such as the "love for our land" and the "pride in our scientific culture" that were stated in the curricula show how history's moralizing functions can be pursued in the STEAM context.

Apart from those invoked in parallel with national identification, some moral response goals were less dependent on specific time and region, as illustrated by School D's case. The objective of this curriculum was to "understand the histories and backgrounds of major wars in different periods, weapons used in each war, and the scientific principles applied to these weapons." Through a grasp of the historical, social and scientific implications of each war, the curriculum also aimed for "recognizing not only the value of science but also the dangers, impacts and ethics of wars that are caused by scientific advancement." This consideration of science's double-sidedness by looking into the history of wars offers an interesting example of useful learning goals that can emerge at the interface of STEM and history.

\section{Exhibition goals}

One dominant feature of the STEAM curricula was the inclusion of activities to display and exhibit student's learning in various forms. Such exhibition goals were particularly visible and richly expressed when language and literature teachers and art teachers were included in the team. The exhibition activities ranged from presenting the result of historical analysis to writing a short essay from the viewpoint of a seventeenth-century European in the face of the scientific revolution. Specifically, we identified four types of exhibition goals based on the skills to be displayed through the activity (Table 3 ).

The first two types of exhibitive goals were broadly concerned with displaying students' explanatory skills and understandings. Both scientific and historical explanation was sought, but the latter goal was more prevalent. Exhibition of scientific explanation was found in School M' s curriculum, where students were asked to "look into the traditional science and technology related to Tripitaka Koreana and present the findings to peers." A specific example of this was to ask students to "explain how the structure of the building ventilates air using Bernoulli's principle." Aside from scientific analysis, eight (62\%) of the curricula included the aim of displaying students' various historical explanation skills. An exemplary case was School B's curriculum that featured diseases in history. Within the topic of infectious diseases and antibiotics in history, in one of their activities, students were introduced to how diseases influenced four wars in history: the Crusades, the Crimean War, the Russo-Japanese War, and the Imjin War. After this brief introduction, the students were divided into groups to select one of these wars and "systematically summarize the background, process and outcomes of the war," and particularly "what changes or developments were made due to the war." Then the students worked to generate PowerPoint slides or a video clip to share their analysis to the class. Through this two-hour activity, the aim was to "find out and write about the commonalities and developmental aspects from history of diseases and cultural diffusion."

The second major exhibition goal was focused on persuasion, which was identified in three $(23 \%)$ curricula. As Jiménez-Aleixandre and Erduran (2007) noted, persuasion is an important role of scientific argumentation along with justification of knowledge claims. In the analyzed curriculum materials, this goal was manifested in the activities to express moral responses such as national pride and love for 
territory, which is linked to the fact that the three curricula were based on the community or national-level contexts. School K's curriculum presented various exhibition goals about Dokdo. Among its stated learning goals were "to write a poem that represent one's care and love for our land Dokdo," "to write or draw to argue for the significance of Dokdo from a scientific standpoint," and "to express the historical and geographical values of Dokdo in a song and role play." School J's approach to persuasive exhibition was similar but more specific in terms of the targeted audience. One of their exhibition activities was to produce a promotional material (pamphlet) about Mireuksa for foreign visitors, particularly "using its historical significance, background knowledge and scientific principles." These two cases illustrate how persuasive exhibition activities can be used to support the moralizing goals of national history.

Lastly, imaginative exhibition goal was present in two $(15 \%)$ curricula. These activities asked students to put themselves in the shoes of past people and exhibit their understandings in creative writing. School A's curriculum that featured East Asian mythologies had a student activity to write one's own mythology based on the constellations. The curriculum stated that by engaging in this activity, students could understand how mythologies are connected to human lives and "imagine the lives of ancient people and the night sky as imagined by them." Whereas the target of imagined people was ancient East Asians, School H targeted a hypothetical European person who was living the age of the scientific revolution (Table 6). Following two lessons covering the background and key figures and events in science around the time, students were first introduced to the various changes in modern Europe caused the scientific revolution. Students were then asked to empathize with the modern Europeans confronting the radical change in people's perception of nature and display their empathic understanding in creative writing, particularly in the form of a journal entry. Together, these two cases of exhibition goals have important resonance with perspective taking and historical empathy as objectives of history learning (Ashby \& Lee, 1987; Foster, 1999).

\section{Connections between the four history learning goals within STEAM curricula}

One noteworthy trend in the data was that a single curriculum typically targeted more than one history learning goals. Among the 13 curricula, four curricula included all four categories of history learning goals, eight included three of them, and one included two of them. While a full analysis of how these goals were connected in each curriculum is beyond the scope of this paper, this plurality of goals points to the possibility of pursuing various historyrelated goals in the context of STEAM. In this section, we use an excerpt from School H's curriculum to illustrate how multiple learning goals can be presented interconnectedly within a STEAM curriculum. In the first three sessions of the curriculum, the focus is on "understanding the changes in the European society caused by the scientific revolution and Enlightenment." The curriculum presents three learning expectations:

1. Understand the development of the scientific revolution in the seventeenth century, and make a historical evaluation of the scientific revolution using the episode of Newton. (Session 1)

2. Investigate and present the effects of the new discoveries during the scientific revolution influenced the world. (Session 2)

3. Re-experience the changes in the perceptions of European people through historical artifacts. (Session 3)

Table 6 Outline of School H's lesson plan on the scientific revolution (excerpt)

\begin{tabular}{ll}
\hline Phase & Instructional activities \\
\hline Introduction (5 min) & $\begin{array}{c}\text { Teacher presents an anecdote about a modern European person who was fascinated } \\
\text { by scientific experiments, and ask: How did the scientific revolution and the estab- } \\
\text { lishment of mechanics change the perceptions of modern Europeans? }\end{array}$ \\
$\begin{array}{l}\text { Development (40 min) } \\
\text { Teacher presents an artifact showing the perceptions of European people after the } \\
\text { scientific revolution } \\
\text { Students, in groups, discuss the above question } \\
\text { Based on the discussion, write a journal entry from the perspective of a modern } \\
\text { European } \\
\text { - Encourage students to include the changes in human lives and perceptions before } \\
\text { and after the scientific revolution } \\
\text { Encourage students to imagine how the establishment of mechanics would have } \\
\text { changed the perceptions of European people } \\
\text { Teacher summarizes the changes in European society invoked by the scientific revo- } \\
\text { lution, and students present what they learnt from the lesson }\end{array}$ \\
Wrapping up (5 min)
\end{tabular}


In Session 1, the learning expectation includes an analytic goal (historical development) and a moral response goal (critical evaluation of Newton's achievements). In the session, students engage in an activity where they "imagine how shocking the heliocentric model would have been to the people [in the seventeenth century] who held the geocentric view, and present what they think," which represents the imaginative exhibition goal. Session 2 highlights the relationship of the scientific revolution to other events in the historical period such as the industrial revolution, specifically focusing on the advances in classical mechanics. Hence, this session is focused on the analytical goal (correlations between historical events) and explanatory exhibition (presenting the findings). Finally, Session 3 turns to the consequences of the scientific revolution. Students engage with artifacts depicting the views of European intellectuals after the scientific revolution, which is aimed at developing analytical skills through working with primary sources. Then, students discuss the influences of the revolution in groups and "write a journal entry from the perspective of a modern European after the scientific revolution." Similar to the previous session, this journal writing activity demonstrates the incorporation of the imaginative exhibition goal.

From these three sessions, we can see how STEM topics (models of the universe, Newtonian science, and classical mechanics) and history learning goals (analytic, moral response, and exhibition) can be coherently integrated to enrich and deepen students' learning of the scientific revolution, a historical event that had widespread impacts on society, culture, religion, and science. The diverse learning goals presented in School H's curriculum show the benefit of STEAM curricula for deep learning of interdisciplinary topics, particularly when developed by cross-subject teams of teachers. A history teacher may not have sufficient knowledge to address the scientific contents necessary to explain the scientific revolution; A science teacher may not be equipped to contextualize the scientific revolution within the broader social and cultural background of the time. In this regard, School H's curriculum can be viewed as a useful case illustrating the potential benefits of cross-subject collaboration in capturing the diverse aspects of a historical event, especially considering that the team included teachers of history, physics and earth science, among others.

\section{Discussion}

\section{Mutual contributions between STEM and history}

The findings illustrate a two-way relationship of STEM and history as school subjects, most notably regarding the analytic goals. Activities such as explaining historical sites and artifacts scientifically and mathematically are good examples. Not only did these activities had the potential to facilitate learning of STEM in the context of history, but they also enrich how we approach historical inquiry in schools. A scientific analysis of artifacts and records to construct scientific accounts of past events can be a useful approach that can serve the goals of both STEM and history education by transcending subject boundaries. Likewise, for the goals relating to identification, moral response, and exhibition, we can see that the integrated STEAM curricula reported in this study broadened the way these history learning goals can be shaped by incorporating STEM subjects. School I's curriculum is a prime example of using a scientific lens to examine a well-known historical artifact and architecture, with identification and exhibition goals embedded within the principally analytic activity. Given these benefits, we suggest that cross-subject collaborations within schools to develop STEAM curricula can be a useful way to enrich the existing goals of history and science learning and explore new learning goals that are of value to both history and STEM education. Considering that this study only focused on cross-subject collaboration, comparative studies on the different modes of history integration with STEM (e.g., non-collaborative and collaborative) will be useful to expand the knowledge about effective STEAM integration in the curriculum.

The frequent inclusion of analytic goals in the STEAM curricula compared to the other three goals warrants further consideration. One possible explanation comes from the framework itself: In Barton and Levstik's framework, the analytic goal is defined broadly in a way it can be related to many elements of the curriculum, ranging from carrying out hands-on activities to considering the causal links between events. It is worth noting that among the different types of analytic goals, the ones that are more closely related to STEM (e.g., explaining causation, process, comparison and arguments) tended to appear more often than analytic skills unique to history (e.g., learning lessons from the past). From these observations, we can see that analytic goals can be a useful common ground to start integration by a group of teachers, but it also suggests that more efforts are called for to explore traditionally overlooked connections between STEM and history. For example, STEAM curricula based on socioscientific issues (Quigley et al., 2020) can explicate the relationship between the identification, analytic, and moralizing goals based on social issues that are highly relevant to students' lives, particularly with the use of exhibitive activities through which students' achievements in these goals can be demonstrated and assessed.

\section{Promises and drawbacks of using the "nation" in STEAM}

It is worth noting how the selection of the central topic, particularly in relation to its regional boundaries, affected the learning goals of each curriculum. For example, the 
prevalence of identification goals in the curricula with the community and national contexts, which were then associated with particular moral responses towards the nation, raises several issues for using history for STEAM education. First, while the use of familiar contexts can make STEAM learning more accessible and enjoyable, it may limit the scope of STEAM to a regional issue and, thus, prevent understanding STEAM within the broader global context. Nevertheless, the two cases where supranatural and universal history were used for identification (School A and School E) provide a rich illustration of contextualizing STEAM in diverse manners that are not confined within a specific national context. These two curricula show the possibility of addressing the transnational histories of STEM in the secondary curriculum (Gandolfi, 2021).

Second, there was some evidence that an overemphasis on moralizing goals such as the promotion of national pride, sense of belonging, and love for territory may work against the analytic goals based on historical and scientific inquiry. In the cases of School M, School K, and School C, several aspects of their analytical activities seemed to begin with a predetermined conclusion (e.g., the "excellence" of ancestor's scientific achievements and the "fabrication" in Japan's claim for sovereignty over Dokdo), followed by a recipe-style procedure for interpreting evidence to reach that conclusion, which has long been criticized by science educators (Erduran \& Dagher, 2014). This trend shows the tension between different goals of history learning that can manifest in the STEAM context, which possibly is tied to the strong moralizing function of school history in East Asian countries (Baildon \& Afandi, 2018; Tohmatsu, 2011). Further considerations will be necessary to balance the identification, moral response and analytic goals in history-infused STEAM curricula.

This is not to say that issues related to nation should be avoided in STEAM learning. Rather, the intersections of STEM and history around the issue of nation can be informed by research on socioscientific issues. SSI researchers have argued that the moral development of children should be a key contribution of STEM education (Zeidler \& Keefer, 2003). Indeed, several key aspects of this study's findings such as argumentation, the nature of science, and empathy are also emphasized in the SSI literature (Sadler $\&$ Dawson, 2012). When dealing with sensitive and contentious issues, approaches such as perspective taking (Kahn \& Zeidler, 2019; Newton \& Zeidler, 2020) can be useful to develop students' moral and emotional responses to a STEAM issue. By considering the perspectives of different stakeholders about an issue, students can have access to a broader range of evidence and more diverse modes of reasoning, compared to when there exists a predetermined conclusion that needs to be reached. An SSI approach may in turn allow avoiding the simplistic "us vs. them" structure in nation-based STEAM learning and appreciating STEAM more effectively in the contexts that are relevant to students' lives. This approach is also aligned with the recent emphasis on care, ethics and empathy in STEM education that "situates [STEM problems] in the full socio-political context and centralizes issues of justice." (Gunckel \& Tolbert, 2018, p. 938) In this regard, STEAM has the potential to move beyond developing technical solutions to social problems and instead conceiving of them as an intersection of society, politics, economics and history (Gunckel \& Tolbert, 2018).

Underlying the question of "nation" in STEAM integration is the stark difference between STEM subjects and history in terms of their geographical boundaries. Science, mathematics and engineering curriculum is traditionally focused on conveying knowledge shared across nations and cultures (Stanley \& Brickhouse, 1994), which allows little space for consideration of national identity or context. It was relatively recent that these issues started to be discussed in science education in the context of multicultural science education that foregrounds culturally responsive teaching of science (Hodson, 1993; Ogawa, 1995). In contrast, the issue of nations has been at the heart of writing and teaching history (Berger, 2012; Maza, 2017). Such contrasting status of "nation" in STEM and history gives a useful clue to understand the relevant findings discussed here. Given the traditional emphasis on nation states and the emerging criticism of it within history education scholars (Berger, 2012; VanSledright, 2008), the place of the nation in designing STEAM curricula would be an interesting avenue for future research.

\section{Limitations and directions for future research}

The findings should be interpreted with the national and curricular contexts within which these STEAM curricula were developed in mind. Given the rising interest in STEAM and curriculum integration across the world and across grade levels (Corp et al., 2020; Khine \& Areepattamannil, 2018), however, the implications of the current study will be informative to educational systems other than Korea. In addition, while our decision to focus on a small number of cases allowed an in-depth analysis including the subtle nuances within each case, it should be taken as exploratory and illustrative, rather than an exhaustive, analysis. Future research with a larger number of cases will deepen the knowledge as to how history and STEM can create synergies through collaborative, integrated STEAM curricula. Methodologically, given that our focus was the final documents produced by teacher teams, future research that includes teacher interviews and observations of the design process will provide further insights into the lived experiences of teachers and the practical challenges they encounter in integrating history and STEM in the curriculum. Also, due to 
the current study's focus on history learning goals in the curricula, it provides limited information as to how and to what extent different subjects were integrated in each curriculum. In future research, it would be useful to explore different models of STEAM integration including history, using the theories of curriculum integration (Drake \& Burns, 2004). Such an analysis will benefit from different models of curriculum integration-for example, what do multi-, inter-, and trans-disciplinarity (Klein, 2017) mean when it comes to integrating STEM and history? Considerations of the integration models will allow diversifying the STEAM curricula and supporting teachers to try different ways of history integration in STEAM.

Acknowledgements We are grateful to Abigail Branford and two anonymous reviewers for their constructive feedback on the earlier versions of the manuscript.

Funding Not applicable.

Data availability All data used in the study can be accessed at https:// steam.kofac.re.kr/

Code availability Not applicable.

\section{Declarations}

Conflict of interest The authors declared that they have no conflict of interest.

Ethical approval Not applicable.

Consent to participate Not applicable.

Consent for publication Not applicable.

Open Access This article is licensed under a Creative Commons Attribution 4.0 International License, which permits use, sharing, adaptation, distribution and reproduction in any medium or format, as long as you give appropriate credit to the original author(s) and the source, provide a link to the Creative Commons licence, and indicate if changes were made. The images or other third party material in this article are included in the article's Creative Commons licence, unless indicated otherwise in a credit line to the material. If material is not included in the article's Creative Commons licence and your intended use is not permitted by statutory regulation or exceeds the permitted use, you will need to obtain permission directly from the copyright holder. To view a copy of this licence, visit http://creativecommons.org/licenses/by/4.0/.

\section{References}

Al Salami, M. K., Makela, C. J., \& de Miranda, M. A. (2017). Assessing changes in teachers' attitudes toward interdisciplinary STEM teaching. International Journal of Technology and Design Education, 27(1), 63-88.

Allchin, D. (2000). How not to teach historical cases in science. Journal of College Science Teaching, 30(1), 33-37.
Allchin, D., Andersen, H. M., \& Nielsen, K. (2014). Complementary approaches to teaching nature of science: Integrating student inquiry, historical cases, and contemporary cases in classroom practice. Science Education, 98(3), 461-486.

Allchin, D., Anthony, E., Bristol, J., Dean, A., Hall, D., \& Lieb, C. (1999). History of science—with labs. Science \& Education, 8(6), 619-632.

Anderson, B. (1983). Imagined communities: Reflections on the origin and spread of nationalism. Verso Books.

Anderson, L. W., \& Krathwohl, D. R. (Eds.). (2001). A taxonomy for learning, teaching, and assessing: A revision of Bloom's taxonomy of educational objectives. Longman.

Ashby, R., \& Lee, P. J. (1987). Children's concepts of empathy and understanding in history. In C. Portal (Ed.), The history curriculum for teachers (pp. 62-88). Falmer.

Baildon, M., \& Afandi, S. (2018). History education research and practice: An international perspective. In S. A. Metzger \& L. M. Harris (Eds.), The Wiley international handbook of history teaching and learning (pp. 37-60). Wiley.

Barton, K. C., \& Levstik, L. S. (2004). Teaching history for the common good. Erlbaum.

Beane, J. A. (1997). Curriculum integration: Designing the core of democratic education. Teachers College Press.

Bell, D. S. (2003). Mythscapes: Memory, mythology, and national identity. The British Journal of Sociology, 54(1), 6-81.

Bequette, J. W., \& Bequette, M. B. (2012). A place for art and design education in the STEM conversation. Art Education, 65(2), $40-47$.

Berger, S. (2012). De-nationalizing history teaching and nationalizing it differently: Some reflections on how to defuse the negative potential of national(ist) history teaching. In M. Carretero, M. Asensio, \& M. Rodríguez-Moneo (Eds.), History education and the construction of national identities (pp. 33-48). Information Age Publishing.

Breakstone, J. (2014). Try, try, try again: The process of designing new history assessments. Theory and Research in Social Education, 42(4), 453-485.

Broggy, J., O'Reilly, J., \& Erduran, S. (2017). Interdisciplinarity and science education. In K. Taber \& B. Akpan (Eds.), Science education: An international course companion (pp. 81-90). Springer.

Carretero, M. (2011). Constructing patriotism: Teaching history and memories in global worlds. Information Age Publishing.

Cartwright, N. (1999). The dappled world: A study on the boundaries of science. Cambridge University Press.

Cobern, W. W., \& Loving, C. C. (2001). Defining "science" in a multicultural world: Implications for science education. Science Education, 85(1), 50-67.

Colucci-Gray, L., Burnard, P., Gray, D., \& Cooke, C. (2019). A critical review of STEAM (Science, Technology, Engineering, Arts, and Mathematics). Oxford Research Encyclopedia of Education (March 2019). https://doi.org/10.1093/acrefore/9780190264093. 013.398

Colucci-Gray, L., Trowsdale, J., Cooke, C. F., Davies, R., Burnard, P., \& Gray, D. S. (2017). Reviewing the potential and challenges of developing STEAM education through creative pedagogies for 21 st learning: How can school curricula be broadened towards a more responsive, dynamic, and inclusive form of education? British Educational Research Association.

Corp, A., Fields, M., \& Naizer, G. (2020). Elementary STEM teacher education: Recent practices to prepare general elementary teachers for STEM. In C. C. Johnson, M. J. Mohr-Schoroeder, T. J. Moore, \& L. D. English (Eds.), Handbook of research on STEM education (pp. 337-348). Routledge.

De Groot-Reuvekamp, M. J., Van Boxtel, C., Ros, A., \& Harnett, P. (2014). The understanding of historical time in the primary 
history curriculum in England and the Netherlands. Journal of Curriculum Studies, 46(4), 487-514.

De la Garza, A., \& Travis, C. (2019). The STEAM Revolution: Transdisciplinary approaches to science, technology, engineering, arts, humanities and mathematics. Springer.

Drake, S. M. (2007). Creating standards-based integrated curriculum: Aligning curriculum, content, assessment, and instruction (2nd ed.). Corwin.

Drake, S. M., \& Burns, R. C. (2004). Meeting standards through integrated curriculum. Association for Supervision and Curriculum Development.

Drake, S. M., \& Reid, J. L. (2018). Integrated curriculum as an effective way to teach 21 st century capabilities. Asia Pacific Journal of Educational Research, 1(1), 31-50.

Erduran, S., \& Dagher, Z. R. (2014). Reconceptualizing the nature of science for science education. Springer.

Erduran, S., \& Jiménez-Aleixandre, M. P. (Eds.). (2007). Argumentation in science education: Perspectives from classroom-based research. Springer.

Erduran, S., Guilfoyle, L., \& Park, W. (in press). Broadening STEM education through cross-curricular collaboration: The case of argumentation in science and religious education. In Y. Li (Ed.), Changes and innovations in disciplinary and interdisciplinary education in STEM: An international perspective. Springer.

Eurydice. (2011). Science education in Europe: National policies, practices and research. Publications Office of the EU.

Fauvel, J. (1991). Using history in mathematics education. For the Learning of Mathematics, 11(2), 3-6.

Foster, S. (1999). Using historical empathy to excite students about the study of history: Can you empathize with Neville Chamberlain? The Social Studies, 90(1), 18-24.

Fried, M. N. (2014). History of mathematics in mathematics education. In M. R. Matthews (Ed.), International handbook of history, philosophy and science teaching (pp. 669-703). Springer.

Furinghetti, F., Matos, J. M., \& Menghini, M. (2012). From mathematics and education, to mathematics education. In Third international handbook of mathematics education (pp. 273-302). Springer.

Gandolfi, H. E. (2021). Decolonising the science curriculum in England: Bringing decolonial science and technology studies to secondary education. Curriculum Journal. https://doi.org/10.1002/ curj.97

Ge, X., Ifenthaler, D., \& Spector, J. M. (Eds.). (2015). Emerging technologies for STEAM education: Full STEAM ahead. Springer.

Gehrke, N. J. (1998). A look at curriculum integration from the bridge. Curriculum Journal, 9(2), 247-260.

Gunckel, K. L., \& Tolbert, S. (2018). The imperative to move toward a dimension of care in engineering education. Journal of Research in Science Teaching, 55(7), 938-961.

Hadzigeorgiou, Y., Klassen, S., \& Klassen, C. F. (2012). Encouraging a "romantic understanding" of science: The effect of the Nikola Tesla story. Science \& Education, 21(8), 1111-1138.

Hallstrom, J., \& Gyberg, P. (2009). Technology in the rear-view mirror: How to better incorporate the history of technology into technology education. International Journal of Technology and Design Education, 21(1), 3-17.

Hempel, C. G. (1942). The function of general laws in history. The Journal of Philosophy, 39(2), 35-48.

Henriksen, D., Mishra, P., \& Fisser, P. (2016). Infusing creativity and technology in 21st century education: A systemic view for change. Journal of Educational Technology \& Society, 19(3), 27-37.

Hodson, D. (1993). In search of a rationale for multicultural science education. Science Education, 77(6), 685-711.

Hong, O. (2017). STEAM education in Korea: Current policies and future directions. Science and Technology Trends Policy Trajectories and Initiatives in STEM Education, 8(2), 92-102.
International Big History Association. (IBHA). (2021) What is big history?-International Big History Association. Retrieved June 27, 2021, from https://bighistory.org/

Jimenez-Aleixandre, M. P., \& Erduran, S. (2007). Argumentation in science education: An overview. In S. Erduran \& M. P. JimenezAleixandre (Eds.), Argumentation in science education (pp. 3-28). Springer.

Johnson, B. (2003). Teacher collaboration: Good for some, not so good for others. Educational Studies, 29(4), 337-350.

Kahn, S., \& Zeidler, D. L. (2019). A conceptual analysis of perspective taking: Positioning a tangled construct within science education and beyond. Science \& Education, 28(6-7), 605-638.

Khine, M. S., \& Areepattamannil, S. (2018). STEAM education: Theory and practice. Springer.

Klein, J. T. (2017). Typologies of interdisciplinarity: The boundary work of definition. In R. Frodeman (Ed.), The Oxford handbook of interdisciplinarity (pp. 21-34). Oxford University Press.

Korea Foundation for the Advancement of Science and Creativity. (KOFAC). (n.d.). Mission and vision. Retrieved from https:// www.kofac.re.kr/eng/contents/aboutKofac3.do

Kuhn, D., Winestock, M., \& Flaton, R. (1994). Historical reasoning as theory-evidence coordination. In M. Carretero \& J. F. Voss (Eds.), Cognitive and instructional processes in history and the social sciences (pp. 377-402). Erlbaum.

Lam, C. C., Alviar-Martin, T., Adler, S. A., \& Sim, J. B. Y. (2013). Curriculum integration in Singapore: Teachers' perspectives and practice. Teaching and Teacher Education, 31(1), 23-34.

Lee, P. (2007). From national canon to historical literacy. In M. Grever \& S. Stuurman (Eds.), Beyond the canon: History for the twentyfirst century (pp. 48-62). Palgrave Macmillan.

Lee, Y. C. (2018). When technology, science and culture meet: Insights from ancient Chinese technology. Cultural Studies of Science Education, 13(2), 485-515.

Lesseig, K., Slavit, D., Nelson, T. H., \& Seidel, R. A. (2016). Supporting middle school teachers' implementation of STEM design challenges. School Science and Mathematics, 116(4), 177-188.

Marsh, C. J., \& Willis, G. (2007). Curriculum: Alternative approaches, ongoing issues. Pearson Education.

Matthews, M. (2005). The pendulum: Scientific, historical, philosophical and educational perspectives. Springer.

Matthews, M. R. (2014). Science teaching: The contribution of history and philosophy of science (2nd ed.). Routledge.

Maza, S. (2017). Thinking about history. University of Chicago Press.

Medin, D. L., \& Bang, M. (2014). Who's asking? Native science, Western Science, and science education. MIT Press.

Merry, M. S. (2009). Patriotism, history and the legitimate aims of American education. Educational Philosophy and Theory, 41(4), 378-398.

Nagel, E. (1961). The structure of science: Problems in the logic of scientific explanation. Harcourt Brace \& World.

Newton, M. H., \& Zeidler, D. L. (2020). Developing socioscientific perspective taking. International Journal of Science Education, 42(8), 1302-1319.

NGSS Lead States. (2013). Next generation science standards: For States, by States. National Academy Press.

OECD. (2020). PISA 2024 strategic vision and direction for science. Retrieved March 3, 2021, from https://www.oecd.org/pisa/publi cations/PISA-2024-Science-Strategic-Vision-Proposal.pdf

Ogawa, M. (1995). Science education in a multiscience perspective. Science Education, 79(5), 583-593.

Park, W., \& Song, J. (2021). Looking back at "our science" and "our history": An exploration of Korean preservice science teachers' encounters with East Asian history of science. Cultural Studies of Science Education. https://doi.org/10.1007/s11422-021-10060-w

Park, W., Wu, J. Y., \& Erduran, S. (2020). Investigating the epistemic nature of STEM: Analysis of science curriculum documents from 
the USA using the family resemblance approach. In Integrated approaches to STEM education (pp. 137-155). Springer.

Peppler, K., \& Wohlwend, K. (2018). Theorizing the nexus of STEAM practice. Arts Education Policy Review, 119(2), 88-99.

Pleasants, J. (2020). Inquiring into the nature of STEM problems: Implications for pre-college education. Science \& Education, 29, 831-855.

Quigley, C. F., \& Herro, D. (2016). "Finding the joy in the unknown": Implementation of STEAM teaching practices in middle school science and math classrooms. Journal of Science Education and Technology, 25(3), 410-426.

Quigley, C. F., Herro, D., \& Jamil, F. M. (2017). Developing a conceptual model of STEAM teaching practices. School Science and Mathematics, 117(1-2), 1-12.

Quigley, C. F., Herro, D., Shekell, C., Cian, H., \& Jacques, L. (2020). Connected learning in STEAM classrooms: Opportunities for engaging youth in science and math classrooms. International Journal of Science and Mathematics Education, 18(8), 1441-1463.

Rouet, J. F., Britt, M. A., Mason, R. A., \& Perfetti, C. A. (1996). Using multiple sources of evidence to reason about history. Journal of Educational Psychology, 88(3), 478-493.

Sadler, T. D. (2004). Moral sensitivity and its contribution to the resolution of socio-scientific issues. Journal of Moral Education, 33(3), 339-358.

Sadler, T. D., \& Dawson, V. (2012). Socioscientific issues in science education: Contexts for the promotion of key learning outcomes. In B. J. Fraser, K. G. Tobin, \& C. J. McRobbie (Eds.), Second international handbook of science education (pp. 799-810). Springer.

Semken, S., Ward, E. G., Moosavi, S., \& Chinn, P. W. U. (2017). Place-based education in geoscience: Theory, research, practice and assessment. Journal of Geoscience Education, 65, 542-562.

Sharapan, H. (2012). From STEM to STEAM: How early childhood educators can apply Fred Rogers' approach. Young Children, 67(1), 36.

Spector, J. M. (2015). Education, training, competencies, curricula and technology: Full STEAM ahead. In X. Ge, D. Ifenthaler, \& J. M. Spector (Eds.), Emerging technologies for STEAM education (pp. 3-14). Springer.
Spoehr, K. T., \& Spoehr, L. W. (1994). Learning to think historically. Educational Psychologist, 29(2), 71-77.

Stanley, W. B., \& Brickhouse, N. W. (1994). Multiculturalism, universalism, and science education. Science Education, 78(4), 387-398.

Taylor, S. J., \& Bogdan, R. (1998). Introduction to qualitative research methods: A guidebook and resource (3rd ed.). Wiley.

Tohmatsu, H. (2011). Japanese history textbooks in comparative perspective. In G.-W. Shin \& D. C. Sneider (Eds.), History textbooks and the wars in Asia: Divided memories (pp. 115-139). Routledge.

Van Drie, J., \& Van Boxtel, C. (2008). Historical reasoning: Towards a framework for analyzing students' reasoning about the past. Educational Psychology Review, 20(2), 87-110.

VanSledright, B. (2008). Narratives of nation-state, historical knowledge, and school history education. Review of Research in Education, 32(1), 109-146.

Yacoubian, H. A., \& Hansson, L. (2020). Nature of science for social justice. Springer.

Yin, R. K. (2017). Case study research and applications: Design and methods. Sage.

Yuen, T., \& Byram, M. (2007). National identity, patriotism and studying politics in schools: A case study in Hong Kong. Compare: A Journal of Comparative and International Education, 37(1), 23-36.

Zeidler, D. L. (2014). Socioscientific issues as a curriculum emphasis: Theory, research, and practice. In N. G. Lederman \& S. K. Abell (Eds.), Handbook of research on science education, Volume II (pp. 711-740). Routledge.

Zeidler, D. L., \& Keefer, M. (2003). The role of moral reasoning and the status of socioscientific issues in science education. In D. L. Zeidler (Ed.), The role of moral reasoning on socioscientific issues and discourse in science education (pp. 7-38). Springer.

Publisher's Note Springer Nature remains neutral with regard to jurisdictional claims in published maps and institutional affiliations. 